\title{
A gyermekek helye és szerepe a hetelő családokban - szülői döntések, nevelés
}

\author{
NEMES-ZÁMBÓ GABRIELLA ${ }^{1}$
}

\section{ABSZTRAKT}

A tanulmány olyan családokat vizsgál, melyek egyik vagy mindkét partnere hosszabb idôtartamú távoli munkavégzés céljából hetel. Kutatási kérdéseink azokra a családokra irányulnak, akik gyermeket nevelnek és ennek eredményeként a családi életüket nagymértékben meghatározza az a sajátos múködési mód, melynek alapja a fizikai, érzelmi közelség és távolság változó dinamikája. A kvalitatív eredményeket feldolgozó elemzés a gyermekeket középpontba állítva igyekszik feltárni a hetelés következtében végbement változásokat a családban. Ezek között hangsúlyosan megjelenik a kötődés a családban, a gyermekek gondozása és nevelése, valamint a gyermek helye és szerepe a családban. A vizsgált családok életében különböző szülői attitüdökkel és szülö-gyermek kapcsolatokkal találkoztunk.

KULCSSZAVAK: gyermekek a családban, hetelő családok, gyermeknevelés, családi döntéshozatal, családi szerepek

\section{ABSTRACT}

\section{The place and role of children in long commuting families - parental decisions and upbringing}

The study examines families in which one or both partners are commuting for longer periods (hetelés). Our research questions focus on those families who are raising children. As a result, their family life is largely determined by the specific operation based on the changing dynamics of physical, emotional proximity and distance. The analysis which processes qualitative results focuses on children and reveals the changes that have taken place in the family as a result of long term commuting. These include attachment in the family, the care and upbringing of children, and the place and role of the child in the family. In the lives of the families studied, we encountered different parental attitudes and parent-child relationships.

KEYWORDS: children in the family, long commuting families, bringing up children, family decisions, family roles

\footnotetext{
${ }^{1}$ Debreceni Egyetem, Humán Tudományok Doktori Iskola, Szociológia és Társadalompolitika Doktori Program, nemes.zambo.gabriella@arts.unideb.hu
} 


\section{TEMATIKUS TANULMÁNYOK - „Hetelők” Kelet-Magyarországon}

\section{Bevezetés}

Jelen tanulmány keretében egy kvalitatív kutatás részeredményeiről számolunk be. A 2019-es kutatás a hosszabb időtartamú távoli munkavégzésre - a megfogalmazásunkban hetelésre - fókuszál. Célja, hogy feltárja azon családok mindennapi életének egyes dimenzióit, melyekben a partnerek valamelyike vagy mindkét fél távolabbi településen hosszabb ideig munkát végez, így az otthonában töltött időtartam lényegesen lerövidül, hetente vagy ritkábban látogat csak haza. A kutatás során mind a hetelő, mind az otthon maradt féllel készültek interjúk, melyek néhány pár esetében lehetővé teszik, hogy komplexen, mindkét partner válaszait figyelembe véve tárjunk fel bizonyos családon, háztartáson belüli jelenségeket, problémacsoportokat. Ugyanakkor azokban az esetekben, melyek során csak a hetelő fél egyikével készült interjú, lehetőségünk nyílt az otthon maradt partnerek jellemző nehézségeit, problémáit felszínre hozni, és mintázatokat találni.

Elemzésünk a kutatás több dimenzióját érintve azzal a kérdéskörrel foglalkozik, hogy milyen változások mennek végbe a gyermekkel rendelkező háztartások, családok életében a hetelés következtében, valamint a gyermekek helye a családon belül hogyan határozható meg. Kíváncsiak voltunk arra, hogy mennyiben alakul át a családon belüli dinamika és munkamegosztás kifejezetten a gyermekekre összpontosítva. Mindehhez szisztematikusan áttekintjük a gyermek-szülő kapcsolat több aspektusát: a kötődést, a gyermekek nevelésének módjait, valamint a gyermekek feladatait, döntési folyamatokban való részvételét.

Az elemzés segítségével betekintést nyerhetünk a napjaink társadalmát nagymértékben meghatározó munkaerőpiaci folyamat - a hetelés - következtében változó családok életmódjába, mindennapjaiba. Különös tekintettel a gyermekek családon belüli szerepére, felelősségkörére vonatkozóan igyekszünk feltárni a gyermekek családon belüli helyzetét.

A tanulmány során az elméleti kereteket megteremtve, korábbi kutatási eredményeket felhasználva igyekszünk a fenti kérdéseket áttekinteni. Néhány interjúrészlettel illusztráljuk a vizsgált kérdéseket, melyek egyrészről alátámasztják az általunk hangsúlyosnak vélt eredményeket, másrészről segítik az olvasót abban, hogy betekintést nyerjen a hetelő családok mindennapi életébe.

\section{Elméleti keretek}

A család a társadalom egyik alapvető egységeként nemcsak a családdal kapcsolatos funkciók betöltéséért felelős, hanem egyúttal az uralkodó társadalmi normák, elvárások egyik meghatározó színtere is (Bánlaky 2004; Schadt 2000). Satir (1999) szerint a család, akárcsak a társadalom maga, szerepekből épül fel, tagjai kommunikálnak egymással, bizonyos célok elérése érdekében pedig döntéseket hoznak. Négy alapvető aspektust határoz meg, melyek a családi élet vonatkozásában jelentősek: 


\section{TEMATIKUS TANULMÁNYOK - „Hetelők” Kelet-Magyarországon}

„- önértékelés

- kommunikáció

- szabályok (a családi élet, rendszer alapkövei)

- társadalommal való kapcsolat.” (Satir 1999: 16)

A jól működő családokat ezen aspektusok alapján vázolja fel, melyben a tagok önértékelése magas szintű; a kommunikációt nyíltság és tisztaság jellemzi; a szabályok nem merevek, hanem alakíthatóak; a társadalommal való kapcsolat pedig nyitottságon alapul (Satir 1999: 17).

Bánlaky Pál (2004) rendszerként tekint a családra, melynek elemei a családtagok. Ők maguk felelősek a rendszer működtetéséért. A családi kapcsolatokat alapvetően a „kölcsönösség-igényü szeretet”, valamint az érzelmi vezéreltség határozza meg (Bánlaky 2004: 10-11). Funkciói vonatkozásában jelen tanulmány témáját tekintve a család egyik legjelentősebb feladata - a szellemi, kulturális, reprodukciós és közéleti-politikai, gazdasági funkció mellett - a pszichoszociális funkciók betöltése, a szocializációs funkció, valamint a gondozó-ellátó funkció. A pszichoszociális funkció biztosítja a családtagok számára az érzelmi kapcsolatok kialakítását és fenntartását (kötődés), míg a szocializáció a gyermekek későbbi sikeres társadalmi integrációjának egyik legfontosabb feltétele, mely alapvetően a szülői minták által determinált (Bánlaky 2004; Schadt 2000). A gondozó-ellátó funkció pedig saját maguk ellátására képtelen családtagok gondozását biztosítja (Bánlaky 2004). A gyermekek nevelése és gondozása tekintetében három dimenziót azonosított Lamb (1986), mely meghatározza a szülői nevelést, egyben a nevelés legfőbb aspektusait. A szülő-gyermek közötti interakciók, a szülő fizikai és pszichológiai jelenléte, elérhetősége, valamint a szülői felelősségvállalás, a gyermek jólétének biztosítása mind a nevelés részei (Lamb 1986 idézi Murinkó 2014).

A gyermekek fejlődésével szoros összefüggésben állnak továbbá a családon belüli kötődések, tehát maga a családi kohézió. Jóllehet, a szociológia főként a szociálpszichológia és pszichiátria fogalomtárából örökölte meg a kifejezést, de a családi élet belső működésével, a családi együttlétekkel és közös tevékenységekkel a szociológia is foglalkozik. A kohézió összetett jelenség, hangsúlyos eleme az együtt töltött idő, illetve annak különböző formái, amit számos faktor befolyásol - többek között a családban uralkodó értékek, minták (Harcsa 2014a). A családon belüli kapcsolatokat és kötődéseket elsősorban a szülők közötti reláció határozza meg, mely szükséges feltétele a családon belüli kohézió stabilitásának és fenntartásának (Magyar 2006). A gyermek szülőkkel való kapcsolatának egyik meghatározó eleme a folyamatos jelenlét, ami biztosítja a stabilitást. Napjainkra mind az anyai, mind az apai családon belüli szerepek és elvárások nagyban módosultak, az apa nevelésben és családi életben betöltött szerepe fokozódott. Az apa hiánya a családi életben és mindennapokban ennek eredményeként merőben más jelenséggé vált, ami már nemcsak a fizikai távollétet jelenti bizonyos esetekben, hanem az apa gyermekekhez való kapcsolódá- 


\section{TEMATIKUS TANULMÁNYOK - „Hetelők” Kelet-Magyarországon}

sának, emocionális támogatásának hiánya is a családi élet deficiteként értelmezhető (Busi 2006, Hegedűs 2006). Az apa nevelésben vállalt szerepét és az apai identitást nagymértékben befolyásolja az édesanya munkaóráinak száma, valamint az anya megítélése a férfi nevelését illetően (Rane - McBride 2000).

A kötődés és a gyermek-szülő kötelék kialakulása és fenntartása azonban a szülői erőforrások gyermekeknek történő átadását is megkívánja. Ezen folyamat részeként materiális (vagyon, jövedelem) és nem materiális javak (értékek, preferenciák, kulturális tőke) átadása valósul meg, mintegy a szocializációs folyamat részeként (De Jong Gierveld et al. idézi Murinkó 2013: 26). Hasonlóan jelentős szerepet játszik a gyermekek fejlődésében a különböző tőkék szülői átörökítése, melyet akár a bourdieu-i (1997) gazdasági, társadalmi és kulturális tőke keretrendszerében, akár a colemani (1988) társadalmi tőke hangsúlyú elméleti megközelítésben is vizsgálhatunk. Amennyiben kifejezetten az oktatási sikerességre koncentrálunk úgy azt látjuk, hogy az emberi tőke (szülői iskolázottság) és a társadalmi tőke (emberek közötti viszonyok rendszerében értelmezendő), megléte önmagában nem elegendő a gyermek iskolán belüli boldogulásához, a szülők folyamatos fizikai és pszichológiai jelenléte szükséges az említett folyamat megvalósulásához. Thomsen (2015) hasonlóan megerősítette, hogy a szülők gyermekükkel töltött idejének hatása van a gyermek iskolai teljesítményére. A gyermekükkel húsz percnél több fejlesztésre fordított időt eltöltő szülők gyermekei szignifikánsan jobban teljesítettek az iskolában.

Az egyén fejlődését Welch (1987) a környezet (természeti, társadalmi) és az egyén közötti hatások, kölcsönhatások dimenziójában határozza meg. Ezek alapján hét különböző szintet különböztet meg az említett relációt tekintve: fizikai; intraperszonális; interperszonális; család; helyi közösségek; kulturális; állam, nemzet. A szintek funkcionális és diszfunkcionális működési mechanizmusait leírva beazonosíthatóvá válnak azok a feltételek és deficitek, melyek az egyén fejlődésének mozgatórugói, esetleges gátjai. A családi színtérnek támogató hátteret, hozzátartozás élményt és megfelelő kapcsolatokat kell biztosítania ahhoz, hogy a fejlődés megvalósuljon. Amennyiben ezek a feltételek nem teljesülnek, a probléma nem csak az adott szint működésében érhető tetten, hanem a modell szerint a további szintekre is hatással lehet. Így a gyermekek családon belüli kapcsolatainak stabilitása, a támogató háttér megléte, valamint az érzelmi támogatás elengedhetetlen a megfelelő fejlődés érdekében (Woods 1994).

A családon belüli kohézió, a családon belüli szerepek változása kapcsán főként az időmérleg vizsgálatok, valamint a különböző kifejezetten ezen a területen készült kutatások lehetnek árulkodóak. Napjaink gyermekgondozási trendjét nagymértékben meghatározza az elmúlt évszázadban végbement strukturális változások hatása. Ennek egyik jelentős folyamata a nők széleskörű munkavállalása (Murinkó 2014).

Szisztematikus nemzetközi szakirodalom elemzés eredményeként Szczuka és munkatársai (2018) azt találták, hogy a szülői munkavállalás jelentős hatással bír a gyermekek jóllétére. Ennek egyik lényegi aspektusa, hogy a szülői munkavállalás 


\section{TEMATIKUS TANULMÁNYOK - „Hetelők” Kelet-Magyarországon}

eredményeként mennyiben módosul az együtt töltött idő tartalma, minősége. Hasonlóan releváns, hogy az átlagostól eltérő munkabeosztás és a gyermekek jólléte között közvetlen negatív hatás figyelhető meg. Egy hazai időmérleg kutatás szerint a szülők mindennapjainak szerves részét képezi a gyermekekről való gondoskodás, a társasági élet egy részét a gyermekekkel való kommunikáció teszi ki (Sebők - Sik 2004). A vizsgálatok azt erősítik, hogy a nő egyszemélyben vagy a férfival közösen látja el jórészt a gyermekek nevelését és gondozását. A gyermekekkel kapcsolatos szülői munkamegosztást azonban jellemzően a szülők értékbeállítódásai határozzák meg (pl. egalitárius értékek mentén élő háztartásokban nagyobb arányúak a közösen végzett munkák, a férfi önállóan több feladatok végez el). A döntően elégedett válaszadók között azonban megjelenik a férfiak egy elégedetlen csoportja a nevelésre vonatkozó munkamegosztást illetően, azok körében, akik szeretnének nagyobb szerepet vállalni az említett feladatokban (Murinkó 2014).

Más kutatások szintén alátámasztják, hogy a nevelési feladatok mára árnyaltabban oszlanak meg a szülők között, mint korábban. A nők szerepe főként a közvetlenül a neveléssel kapcsolatos tevékenységekben hangsúlyos, a további tevékenységekben azonban jelentős szereplő lehet a férfi is (pl.: szabadidős tevékenységek) (Harcsa 2014a). Változások érzékelhetőek továbbá a "gyermekgondozásra és nevelésre fordított „időalap” belső szerkezetét” tekintve, ugyanis jelentősen nőtt a mesélés és a játékra fordított idő mennyisége, amely változásban hangsúlyosan az apák érintettek inkább (Harcsa 2014b).

\section{Módszertan}

A kutatás 2019 nyarán-őszén zajlott, mely során 24 interjú készült hetelésben érintett párok, családok felnőtt tagjaival. A mintavétel nem valószínűségi, a kiválasztás során elsődleges szempont volt, hogy (1) a távolabbi településre ingázás heti egyszeri vagy kéthetente, háromhetente történő hazalátogatást tegyen lehetővé. Továbbá, hogy (2) Kelet-Magyarországon található lakóhellyel rendelkezzen a megkérdezett, és (3) jellemzően faluban, kisvárosban éljen. A kapcsolatokat és ismertségeket alapul véve négy megye területén (Hajdú-Bihar megye, Szabolcs-Szatmár-Bereg megye, Jász-Nagykun-Szolnok megye és Borsod-Abaúj-Zemplén megye) jellemzően kistelepüléseken készültek interjúk.

A minta 24 interjúból épül fel, melyből 10 interjú koncentráltan, egy településen került felvételre. Ez az települési koncentráció lehetővé tette, hogy az öt pár mindkét tagjával készüljön interjú. A további interjúk elszórva, kistelepüléseken készültek. A fennmaradt 14 interjúból 4 párral (8 db páros interjú) és 6 otthon maradt partnerrel készült. Ennek eredményeként a megkérdezett interjúalanyok között 15 nő és 9 férfi szerepel, a nők azonban nem minden esetben otthon maradó felek, néhányuk a partnerhez hasonlóan hetelő munkát végez. A megkérdezett hetelők többsége belföldön 


\section{TEMATIKUS TANULMÁNYOK - „Hetelők” Kelet-Magyarországon}

dolgozik, akadnak azonban olyan alanyok is, akik külföldi munkatapasztalattal rendelkeznek.

A kutatás megvalósításához két mérőeszközt fejlesztettünk ki, melyek néhány közös blokkal, de az otthon maradt és a hetelő félt külön megcélozva igyekezett feltárni a hetelés családi életre kifejtett hatását. Külön egységben foglalkoztunk:

- a család életkörülményeivel és pénzgazdálkodásával,

- a munkatapasztalatokkal,

- a heteléssel, a családi élettel,

- a párkapcsolattal, valamint

- a helyi közösséggel (amennyiben ez releváns volt).

A két mérőeszköz célja egyben az is volt, hogy a két különböző narratíva betekintést engedjen az esetleges konfliktusok, problémák alakulásába, dinamikájába, valamint komplexebb megközelítést tegyen lehetővé az említett kérdéskörökben.

Az itt következő elemzésben az összes interjút felhasználva, de különös tekintettel a gyermekes háztartások tapasztalatait, jellemzőit vizsgálva igyekszünk áttekintést nyújtani a kutatás eredményeiről az említett témakörben.

\section{Eredmények}

Az elemzés során elsődlegesen a gyermekes családokra fókuszálunk. A kilenc megkérdezett párból három pár nem rendelkezett még gyermekkel az interjú készítésének időpontjában, a hat női interjút tekintve csak egy esetben gyermektelen a háztartás. A gyermektelen háztartásokkal kapcsolatban elmondható, hogy mindegyikük tervez gyermeket, de a gyermekvállalást bizonyos feltételekhez kötik, melyek többnyire a lakhatással függnek összes (pl. építkezés befejezése, lakásvásárlás stb.). Esetükben a számunkra releváns kutatási alkérdéseket nem tudtuk elemezni.

Az eredmények bemutatása során tehát a gyermekes családok életébe nyújtunk betekintést. A kutatás dimenziói fóként a hetelés családi életre gyakorolt hatásának témakörében foglalkoztak a gyermekek helyzetével (családon belüli feladatok, gyermekek nevelése, kapcsolattartás, döntéshozatal), azonban más dimenziók esetében is felmerült a gyermekek családon belüli szerepe. A továbbiakban a családi élet dimenzióján belül vizsgálódunk, egyrészről kitérünk a gyermek-szülő közötti kötődés és ragaszkodás különböző megéléseire és változataira a hetelő családokban, másrészről a gyermekekkel kapcsolatos mindennapi tevékenységek, valamint a nevelés egyes aspektusait is vizsgáljuk. Hasonlóan részletesen foglalkozunk a gyermekek helyével és szerepével a családban, melyet a gyermekek háztartási feladatokba történő bevonásával, a gyermekek jövőtervezésben játszott szerepével, valamint a kisgyermekes és nagyobb gyermekkel rendelkező háztartások különbözőségeivel igyekszünk felvázolni. 


\section{TEMATIKUS TANULMÁNYOK - „Hetelők” Kelet-Magyarországon}

\section{KÖTŐDÉS A CSALÁDON BELÜL}

A gyermekekkel kapcsolatos egyik központi témakörként a ragaszkodás és kötődés kérdése merült fel. A gyermekes családok többsége a hetelés hátrányaival, a hetelés családi életre gyakorolt hatásával való összefüggésben említette meg, hogyan változott a gyermek-szülő kapcsolat tartalma és dinamikája. A gyermekes háztartások jellemzően maximum három gyermekkel rendelkeznek, de kétgyermekes és egygyermekes háztartások is találhatóak az interjúalanyok között. A kötődés kérdése főként a hetelő szülő vonatkozásában érdekes, hiszen ebben az esetben a szülő fizikai és pszichológiai jelenléte nem konstans, a kapcsolat dinamikáját elsősorban a hetelés-otthon töltött idő kettőssége határozza meg.

A kötődés és ragaszkodás mértékét jelen kutatás kereteiben nem tudjuk mérni, de a kötődést leginkább meghatározó dimenziók vonatkozásában három olyan mintázatot találtunk, melyek bizonyos tényezők eredményeként különböző szülő-gyermek kötődési viszony megéléseket idéztek elő.

Néhány család esetében (1) a hetelés egy természetes jelenség, a családi élet szerves része, mely nem pozitív vagy negatív, inkább semleges kategória. Ezekben a családokban a szülő-gyermek kötődését alapvetően ez a kiindulási pont határozza meg. Körükben a kötődés és a ragaszkodás nem központi elem, ezen érzelmi viszonyulást nem tárgyalják széleskörűen. Közöttük két altípussal találkoztunk, azon családokkal, ahol a gyermek születése óta zajlik a hetelési folyamat és a gyermek „ebben nőtt bele", valamint azokkal a családokkal, ahol az idősebb gyermekek ellátásának, boldogulásának ez az egyik alapfeltétele.

„A kisebbik fiam is örül neki, hogy eljárok, mert úgy iskolába tud járni, ruháztatni kell, kollégista, ebédet kell neki fizetni, útiköltségek, mikor hazajár, meg azért megvenni neki a ruházatot, táska, minden." (3 nagykorú gyermeket nevelő, hetelő családapa)

„Úgymond megerôsödtünk, végül is már most erre az életre álltunk be úgymond. Tehát a gyerekek is ezt szokták meg. Hétközben is mindenki szalad, volt úgy, hogy egyedül voltam itthon, mert ugye a kicsi még nem volt, a két nagy gyerek kollégiumban, ő ugye dolgozott, és hétvégén mindenki hazaesett. Most a lányokkal vagyunk itthon hárman hétközben, de mindenki mindenkivel tud beszélni, hogyha arról van szó, meg ugye a kapcsolattartás sem olyan már, mint 20 évvel ezelött." (3 gyermeket nevelő, otthon maradó édesanya)

A szülő-gyermek viszonyt elsősorban a hetelés következtében kialakult megszokások, érzelmi megnyilvánulások határozzák meg, bár felsejlik az igény a szülő aktívabb jelenlétére és a hiány is megjelenik mind a szülők, mind a gyermekek tekinte- 


\section{TEMATIKUS TANULMÁNYOK - „Hetelők” Kelet-Magyarországon}

tében, de a kötődést elsősorban a hetelés, mint szükséges vagy természetes folyamat relációjában élik meg az alanyok.

Ugyanakkor találkoztunk olyan interjúalanyokkal is, akik a hetelés és a szülő-gyermek kapcsolat pozitív hatásairól számoltak be. Olyan családokról van szó, akik (2) a kötődés megerősödését, a ragaszkodás fokozódását élték meg az említett relációban. Közöttük találtuk meg azokat, akiknek mindkét szülő esetében fokozódott a kötődés és a szeretetélmény a gyermekek irányából a szülők irányába, a két szülő között ez kiegyenlített volt, valamint szintén ebbe a kategóriába sorolhatók azon családok, ahol a hetelő szülő irányába történt erőteljes eltolódás a ragaszkodás tekintetében. Az első alkategóriában szerepelnek tehát azok a családok, akik esetében a gyermekek a hetelő hazaérkezésekor nagymértékű örömöt, kötődést élnek meg, a kapcsolattartás a távollétükben is aktív, de mindez nem befolyásolja az otthon maradó féllel kapcsolatos kötődést.

„...tehát ez nem egy szerencsés helyzet, de minden nap beszélnek, fél órát telefonon, meg korrepetálja őket angolból telefonon keresztül, tehát a kapcsolat megvan." (Két gyermeket nevelö, otthon maradó nő)

Másik alkategóriaként azokat a családokat azonosítottuk, amelyek esetében a kapcsolat és a kötődés mértéke rendkívül intenzívvé válik a hetelő hazaérkezésekor és ez a másik szülő felé történő ragaszkodást is csökkenti az adott időszakban.

„Hát [gyermek], ha haza jön apa, akkor ő az első. Akkor az apa hiányt, akkor csak apa mikor kisebb volt. Még most is, de igen, ő ragaszkodik mindkettőnkhöz. Ha én vagyok akkor énhozzám, ha az apja van, akkor őhozzá." (Egy gyermeket nevelö, otthon maradó édesanya)

\section{- A gyerekekkel változott a kapcsolatotok?}

„Hát ezt nem tudom, biztos változott, jobban hiányoznak. Gondolom, nekik is. Abban változott ugyi, hogy én a gyerekekkel egész közel vagyok. Itt van nekem a nagyfiam, 18 éves, de az ölembe ültetem, megpuszilom, úgyhogy egészen közel állunk egymáshoz." (Három gyermeket nevelő, hetelő édesapa)

Mindkét esetet természetes folyamatként írhatjuk le, a gyermekek kora, valamint a családon belüli kötődések különböző dinamikákat eredményeznek a családon belül.

Harmadik mintázatként elenyésző számban ugyan, de rendkívül erőteljesen nyilvánult meg az a jelenség, mely a hetelő szülővel szemben tapasztalt idegenségérzést, részleges érzelmi eltávolodást jelezte. 


\section{TEMATIKUS TANULMÁNYOK - „Hetelők” Kelet-Magyarországon}

„A legidősebb S. aztán N. a két fiatal között az 3 év van, az életéből elég sokat kiestem, akkor még úgy dolgoztam, hogy 3 hét kint, néhány nap itthon, abból az éveiből kiestem, ez egyébként látszik rajta, most, ha hazajövök akkor egy hétig szok, aztán elkezd emberszámba venni, de egy hétig nem vesz emberszámba, sôt menekül előlem, amikor bejövök a lakásba menekül ki ordítva. És akkor miután egy hétig itthon vagyok, akkor megszok' engem, meg úgy ahogy elfogad. A másik kettő, hát a legjobban szerintem a középső a K. szeret engem, elmegyek érte az óvodába, akkor odajön hozzám, átölel, ó úgy kezdi, neki ez a hetes dolog nincsen, ő egyből szeret engem. Hát N. meg anyás, ő neki is megvan ez az egy hetes intervallum, addig kerül engem, összeveszünk, nem szeret engem olyankor, mert sokat tévézik, de most már hogy itthon vagyok több mint egy hete már idejön hozzám, hogy ezt olvassam fel neki a meséket, meg ezt meg azt, neki is kell pár nap, de azért megszok'”' (Három gyermeket nevelő, hetelő édesapa)

Az alanyok körében tehát előfordultak olyanok, aki természetesnek vélték és egyben elsősorban a hetelés által meghatározottnak gondolták a szülő-gyermek viszonyt, voltak, akik pozitív változást, esetleg negatív irányú átalakulást érzékeltek a gyermek-szülő kapcsolatban. Az elmondottak alapján azonban kirajzolódott, hogy főként a hetelő fél él meg nehézségeket, akadályokat a kötődés fenntartásában és ápolásában. Míg néhány esetben ezeket a nehézségeket nem sikerül leküzdeni, máshol az együtt töltött idő minősége felértékelődik, a kötődés intenzitása megnő. A mindennapos kapcsolattartás azonban a kötődés és ragaszkodás fenntartásának egyik alapfeltételeként fogalmazódott meg: a történésekbe való bevonódás, a mindennapi események meghallgatása, a tanulásban való részvétel mind hozzájárulhatnak az említett folyamathoz. Összességében az interjúalanyok többsége beszámolt arról, hogy a gyermekeknek nehézséget jelent a szülő távolléte, melyhez a lehetőségekhez mérten mindenki igyekszik alkalmazkodni.

„...ez, hogy hétfön kell már visszajárnia, tehát a péntek, szombat, vasárnap itt van, én azt gondolom, hogy ez mindig viszonyítás kérdése, aki kéthetente meg havonta jár haza, ahhoz képest mi borzasztó szerencsés helyzetbe vagyunk. Nyilván ahhoz képest meg, hogy itthon lenne, ahhoz képest nem, de hát ez ilyen." (2 gyermeket nevelő, otthon maradó nő)

\section{A GYERMEKEK GONDOZÁSA, NEVELÉSE}

A gyermekek nevelése az interjúalanyok elmondása szerint komplex feladat, magában foglalja nemcsak a gyermekek fizikai szükségleteinek kielégítését, hanem egyben érzelmi és kognitív nevelését is. Az interjúalanyok között előfordult, hogy az 


\section{TEMATIKUS TANULMÁNYOK - „Hetelők” Kelet-Magyarországon}

otthon maradt fél egyszemélyben minden felelősséget magára vállalva látja-e el a gyermekek gondozását és nevelését, de találkoztunk olyan családdal is, ahol a hetelő szülő lehetőségeihez mérten igyekszik kivenni a részét a feladatokból. Bizonyos családok esetében tudatos döntésről van szó, mások esetében a szokásjog vagy a tradicionális családi értékek magyarázzák a neveléssel kapcsolatos szereposztást.

Természetes, hogy a gyermekek ellátását és gondozását a hétköznapokon, illetve azokban az időszakokban, amikor a hetelő fél nem tartózkodik otthon, a nem hetelő fél látja el. Ezeket a feladatokat kivételes esetekben - például abban az esetben, ha mindkét fél hetel - a nagyszülők, más rokonok is magukra vállalják. A nevelés néhány esetben a családon belüli munkamegosztás egy részeként jelenik meg, máshol inkább a családi életben végbement változások között merül fel.

A nevelési folyamatba való bevonódás egyik fokmérője lehet a szülők gyermekekkel kapcsolatos döntésekben való részvétele. Ennek eredményeként találhatunk olyan családokat, ahol az édesanya (otthon maradt fél) jár el teljeskörüen a gyermekek nevelésében.

„-És mennyire vonódsz be a napi döntésekbe a család életében?

- Hát most mi a napi döntés, hogy mi az ebéd?

- Akár...

- Én azt sem tudom, hogy milyen az ebéd... itt nálunk nincsenek hatalmas döntések, most az autóvásárlás előtt állunk, ezen gondolkodunk, megbeszéljük a dolgot vagy 18-szor, amiket szoktunk venni drágább dolgokat, azokat is megbeszélgetjük, nálunk ilyen dolgok nincsenek. Cipővásárlást azt rábízom, meg kabátvásárlást, ennyi, meg a gyerek milyen szakkörre járjon azt rábízom, mondjuk elég sok már, rá kell szólnom, mert az se jó, ha minden nap valamit csinál..." (Három gyermeket nevelő, hetelő édesapa)

Tudatos döntésre is van példa ezen szülők között, amely esetben szintén az édesanya jár el a neveléssel kapcsolatos kérdésekben.

„Hát, anno, mikor elkezdődött az a fajta időszak, amikor már úgy igazán gyereknevelésre került a sor, akkor úgy eldöntöttük, hogy kettőnk közül ki az, aki nevel. Vagy ő két nap alatt, és nekem ne legyen gond a további 5 nap alatt, vagy rám szorul a nevelés, és akkor nem mindig értettünk egyet, és igen, ez a mai napig is van így, hogy nem mindig értünk egyet, de úgy elfogadja, elfogadta az én döntéseimet. Tehát általában rám maradt a nevelési része." (Két gyermeket nevelö, otthon maradó édesanya)

A közös nevelés részeként a különböző döntési folyamatokban, gyermekeket érintő hétköznapi kérdések megvitatásában jó néhány család esetében közösen döntenek a gyermekek nevelését illetően. 


\section{TEMATIKUS TANULMÁNYOK - „Hetelők” Kelet-Magyarországon}

„Ugyanúgy, telefonon keresztül is megbeszéljük. Mert mondjuk, ha a fiúk szeretnének valamit, mert hogy mondjam egy kicsit kényesek, aztán elöször közlik velem, hogy mit szeretnének, aztán én adjam elő apának. Na és akkor mi azokat telefonon is megbeszéljük, B.-nek most ez kellene, ezt szeretne, egy Huawei telefont, hát mán 200 ezer forint, mondom atyaég te fiú hát honnan adjak neked 200 ezres telefont, hát jó na mert részletre vettem, de rá tudtuk beszélni apukával együtt. Na úgyhogy együtt döntünk mindenben, én nem döntök egyedül, ö sem. Vagy például egy ilyen dolog, egy 200 ezres telefon azért nem csak én csíkzsebből adom eló, hanem ezt mindenkivel meg kell beszélni. Na, de most ezzel férjem is úgy van, hogy mindent megbeszélünk onnan távolból is." (Három gyermeket nevelő, otthon maradó édesanya)

A közös döntések és felelősségvállalás mellett is megjelennek azonban olyan nehézségek, melyek megkívánják a hetelő szülő fizikai jelenlétét. Mintegy félelemként fogalmazódik meg az egyik édesanyában, hogy az egészségére fokozottan oda kell figyelnie, ugyanis betegség esetén a gyermekek magukra maradnának. Ez pedig az önfeláldozás egyik szélsőséges példájaként is azonosítható.

- És esetleg Önnek változott-e a gyerekekkel való kapcsolata?

„Hát, ez eddig is szoros volt, de most igen, persze, én is lehetek rosszul, meg lehetek beteg, amikor egy... amikor én szorulok felnôttként a gyerekemre, és ez nagyon rossz érzés." (Három gyermeket nevelő, otthon maradó édesanya)

A gyermekek nevelése és gondozása tekintetében tehát jelentős szerep jut a döntések meghozatalának, mely akár szokásjogon alapulva, akár gyakorlatias szempontból, de legtöbbször azt eredményezi, hogy a hetelő fél a fontosabb, nagyobb horderejú kérdésekbe vonódik be, míg a hétköznapi problémák esetében inkább az otthon maradó fél dönt.

„Hát tulajdonképpen a férjem csak a végeredményt kapja nagyon sokszor, tehát ha valamit meg kell beszélni, el kell intézni, sokszor csak közlöm vele, hogy na most akkor mentünk és albérletet kerestünk, és megvan, és már beköltöztünk, és ő csak fizet például. Jó megbeszélünk mindent, de tényleg nagyon sok mindenben szinte én vagyok, aki dönt, tehát akár, ha a gyereket orvoshoz kel vinni hirtelen. Volt olyan, hogy a fiammal hamarabb hazaértünk a balesetiröl, mint pénteken este Ausztriából. Persze vannak a nagy elbeszélgetések, meg te tudod fiam, meg de ha rám hallgatsz fiam, mondjuk mióta már most ugye 19 éves lesz a fiam, úgymond a kis kamaszkoron túl van. Már most várjuk, hogy mikor jön meg a jobbik esze, de úgy gondolom, hogy egyre jobban kikéri az apjának a véleményét, tehát már megvannak a férfias beszélgetések, a fiú 


\section{TEMATIKUS TANULMÁNYOK - „Hetelők” Kelet-Magyarországon}

dolgokról meg úgy összességében, meg szakmaválasztás volt augusztusban meg ilyenek, azért úgy veszem észre, hogy igényli." (Három gyermeket nevelö, otthon maradó édesanya)

„Tehát nekem azért ez elég erôs nyomás, hogy itt vagyok a három gyerekkel szinte egymagam, és hogyha valami történik enyém a felelösség, ez azért elég nyomasztó tud lenni az embernek, amikor így éli a nem túl vidám hétköznapokat. De talán már ehhez is hozzászoktam." (Három gyermeket nevelő, otthon maradó édesanya)

\section{A GYERMEKEK HELYE ÉS SZEREPE A CSALÁDBAN}

Amennyiben a gyermekek helyét és szerepét vizsgáljuk a családon belül, egyrészről tehetjük azt a családi munkamegosztásba ágyazva, másrészről a szülők gyermekekkel kapcsolatos jelenkori és jövőbeli elvárásaival, álmaival összefüggésben is. Utóbbi jól érzékelteti, hogy a gyermekek sikerességének, boldogulásának mennyire van központi szerepe a szülők elképzeléseiben.

Többségében a gyermekek - életkoruknak megfelelően - szervesen kiveszik a részüket a háztartási és ház körüli teendőkből, melyek főként a hetelő távollétében relevánsak. Többnyire kisebb feladatokkal bízzák meg őket az otthon maradó szülők, de az idősebb gyerekek akár felelősségteljesebb tevékenységeket is elvégeznek.

\section{- A gyerekeknek vannak otthon feladataik?}

„Hogyne, persze. Leginkább nyári szünetben. Akkor úgy van, hogy teljesen be... egy táblázatba, hogy ki mit. Megcsinálják, meg nyilván a saját dolgaikat. A szennyest kiviszik a mosodába, ha úgy van. Az ő kis szobájukat rendbe rakják. Ezek az alap dolgok megvannak. Tehát én utánuk nem pakolok semmit." (Két gyermeket nevelö, otthon maradó édesanya)

„Hát, ezt konkrétan sosem osztjuk le. Ez valahogy kialakult. A lányok mindenben segítenek, akár nekem, akár a férjemnek, amikor ő itthon van. Legyen az kertészkedés, házimunka, fözés... bármi. Tehát nincs konkrét feladatunk, amit csak egy bizonyos ember végezhet el." (Három gyermeket nevelő, otthon maradó édesanya)

Megjelent továbbá, hogy néhányan igyekeznek a gyermekeket nem túlterhelni és sok esetben az együtt töltött időt inkább beszélgetésre, játékra fordítani, mint a ház körüli teendők elvégzésére korlátozni. A gyermekek azonban nemcsak a mindennapi feladatokban érintettek, hanem a szülők jövőképének, álmainak főszereplői is. Az 


\title{
TEMATIKUS TANULMÁNYOK - „Hetelők” Kelet-Magyarországon
}

interjúalanyok többsége a jövője vonatkozásában a gyermekek boldogulását említette, melynek egyik alapfeltételeként hivatkoztak a hetelői munkavégzésre, mint a szükséges anyagi tőke megteremtésére.

\section{- És milyen közös terveitek vannak a pároddal?}

„Hát nem is tudom. Inkább a ház újítás, azt tervezzük. A gyerekeknek a külön helyet is csináljuk. Tervben ennyi van." (Két gyermeket nevelő, otthon maradó édesanya)

\begin{abstract}
„Közösen fel szeretnénk menni dolgozni, igen, mert a nagyobbik fiammal ki szeretnénk venni egy házat. A középső fiamnak segítettem, kihasználta a szocpolos segélyt, de segítettem, megpótoltam neki tavaly, uborkáztunk, neki gyújtöttünk, most a nagyobbik fiamnak szeretnék venni egy házat, annak gyüjtünk." (Három gyermeket nevelő, hetelő édesapa)
\end{abstract}

Nemcsak az idősebb gyermekek esetében célkitűzés azonban a gyermekek támogatása, hanem a fiatalabbak esetében is. Utóbbiak a megfelelő ruháztatásra, iskoláztatásra való igényben nyilvánulnak meg leginkább. Életkoruknak megfelelően tehát az éppen aktuálisan elérendő cél vezeti főként a szülőket, mely az idősebb gyermekkel rendelkezőknél a lakhatás segítésében, a fiatalabbaknál a szakmaszerzés, iskoláztatás támogatásában mutatkozik meg. A megkérdezett családokban a gyermekek központi helyet foglalnak el mind a mindennapokban felmerülő tevékenységek vonatkozásában, mind a heteléssel való összefüggésben a családi kapcsolatokban, a családi élet dinamikájában.

\section{Összegzés}

Jelen tanulmány keretében arra vállalkoztunk, hogy a 24 heteléssel érintett interjúalany gyermekes tagjainak válaszaiból a hetelő családokban élő gyermekek helyzetét megvizsgáljuk, valamint beazonosítsuk azon legfőbb jelenségköröket, melyek meghatározóak a család mindennapi életét tekintve. Az interjúszövegek és elemzések olvasása után kitűnik, hogy a kutatásba bevont gyermekes családokban rendkívül hangsúlyos szerep jut a gyermekeknek. Akár idősebb gyermeket nevelő szülőkről legyen szó, akár kisgyermekkorban lévő gyermekről, a mindennapi élet megvitatása során számottevően megmutatkozott a gyermekek érdekeinek, jólétének biztosítása iránti igény és gondoskodás.

A mintába került gyermekes háztartásokat három fő dimenzió mentén vizsgáltuk: kötődés a családban; a gyermekek gondozása és nevelése; a gyermek helye és szerepe a családban. Alapvető kiindulási pontként alkalmaztuk, hogy a hetelés követ- 


\section{TEMATIKUS TANULMÁNYOK - „Hetelők” Kelet-Magyarországon}

keztében változások mennek végbe a családi életben, ennek megfelelően nemcsak a háztartással kapcsolatos feladatok és tevékenységek igénylik az újszerű feladatkörök kialakítását, melyekben a gyermekek is érintettek lehetnek, hanem egyúttal a családi kötelékek, az érzelmi kapcsolódások is változni kényszerülnek.

A kötődés tekintetében azonban nemcsak a hetelés következtében végbement kötődési deficiteket tudtuk beazonosítani (elidegenedés, elhidegülés a hetelő szülőtől), hanem olyan eseteket is, amelyek a hetelés természetes mivoltára, annak a kapcsolatokra és kötődésekre kevésbé meghatározó erejére fókuszáltak. Ezen felül néhány esetben pozitívan hatott a hetelés a gyermekek hetelő szülők felé irányuló ragaszkodására és kötődésére, ami az együtt töltött idő felértékelődését, minőségi eltöltését jelentette. Az utóbbi két esetben az interjúalanyok arról is számot adtak, hogy a kötődés fenntartásához elengedhetetlen a rendszeres kapcsolattartás, amihez a modern technológia napjainkban már széles eszköztárral rendelkezik.

A gyermekek neveléséhez és gondozásához kapcsolódóan főként az előbbi kategória vonatkozásában tapasztaltunk direkt vagy indirekt döntéseket és szerep felosztásokat, elvárásokat a szülők között. Legalább olyan hangsúlyosan voltak jelen azon családok, akik teljes mértékben az otthon maradó félre bízták a gyermekek nevelését - szokásjog, tradicionális családi értékrend vagy a praktikum szempontjából -, mint azok, akik közösen viselték a gyermeknevelés felelősségét. Előbbiek között az édesanyák egy része természetes folyamatként érzékelte ezt a felelősséget, míg mások annak nehézségeiről számoltak be.

A gyermekek helyét és szerepét a családban két aspektusból vizsgáltuk. Egyrészről kíváncsiak voltunk arra, hogy a családon belüli feladatokból milyen mértékben veszik ki részüket, kötelező-e a segítségnyújtás. Másrészről a szülők jövőre vonatkozó terveit vizsgáltuk meg. A gyermekek többsége életkorának megfelelően besegít a háztartásbeli és háztartás körüli feladatokba, de a szülők elmondása alapján ezek a folyamatok többnyire természetesen alakulnak ki. A szülők jövőképének és jövőre vonatkozó terveinek minden esetben központi szereplője maga a gyermek, akinek segítése, támogatása a hetelői életmód választásának egyik fő oka.

Összességében elmondható, hogy a hetelés az érintett családokra jelentős hatással van, mely a gyermekek családon belüli szerepét és helyzetét illetően fokozottan tetten érhető. A hetelő-szülő és gyermek kapcsolatot elsősorban a kettősség határozza meg, mely nemcsak fizikailag, de érzelmileg is jelentős. Folyamatosan váltakozik ugyanis a távolság és a közelség, mely nemcsak a gyermekekre, de a szülőkre nézve is sok esetben nehéz pszichés teherként nehezedik. Mindez nemcsak a szülő-gyermek kötődés dinamikáját és tartalmát írja át, hanem egyben a gyermekek nevelésének, gondozásának természetét is megváltoztatja. Ezekben a helyzetekben felértékelődnek a családi erőforrások, a testvérek és az otthon maradt fél között felerősödik a felelősségvállalás, a családok egy része összezár. 


\section{TEMATIKUS TANULMÁNYOK - „Hetelők” Kelet-Magyarországon}

\section{- Esetleg a férjének változott-e a gyerekekkel való kapcsolata a hetelés óta?}

„Igen, hogyne változott volna. Hiába beszélnek ők is telefonon, nem vesz részt ugye a mindennapokban. Látja a kis életüket, amik az iskolában történnek, akár egy fellépésen, egy müsor során, fényképeken, de nem részese egy jelmezkészítésnek. Ha betegek, nem ül mellettük, vagy nem ő viszi őket orvoshoz. Mindenröl csak tud, de nem éli át. Sem a gyerekek, sem ő az eseményeket, és ez kicsit távolabb... távolabb kerülnek ők ezáltal egymástól. Amikor érzelmileg átütőbb dolgokat is mesélnek el, az teljesen más két hét után elmesélni, vagy lehet, el sem mesélik az apjuknak, mint amikor frissiben hazajönnek és el tudják neki mesélni."

\section{Irodalom}

Bánlaky P. (2004): Családszociológia. Wesley János Lelkészképző Főiskola, Budapest Bourdieu, P. (1997): Gazdasági tőke, kulturális tőke, társadalmi tőke. In: Angelusz R. (szerk.): A társadalmi rétegződés komponensei. Budapest, Új Mandátum Könyvkiadó, 156-177.

Busi E. (2006): Az anya-gyerek kapcsolat. In: Hegedűs J. (szerk.): A gyakorlati pedagógia néhány alapkérdése. 19-20.

http://gepeskonyv.btk.elte.hu/adatok/Pedagogia/84N\%E1dasi/Nyomtat\%E1sra/pdf/Csal\%E1d,\%20gyermek,\%20t\%E1rsadalom.pdf (Utolsó letöltés: 2020. 04. 17.)

Coleman, S. J. (1988): A társadalmi tőke az emberi tőke termelésben. In: Perjés I. Kovács Z. (szerk.). (2002): Életvilágok találkozása. Budapest, Aula Kiadó, 130160.

Harcsa I. (2014a): A családi kohézió trendjei a gyermekes családokban. Szociológiai Szemle 24(1): 40-66.

http://szociologia.hu/dynamic/harcsa_40_66old.pdf (Utolsó letöltés: 2020. 04. 17.)

Harcsa I. (2014b): Családi kohézió. A szülők és gyermekek társas együttléte a mindennapok világában. Központi Statisztikai Hivatal, Budapest

http://www.ksh.hu/docs/hun/xftp/idoszaki/pdf/muhelytanulmanyok5.pdf (Utolsó letöltés: 2020. 04. 20.)

Hegedűs J. (2006): Az apa-gyerek kapcsolat. Hegedűs J. (szerk.): A gyakorlati pedagógia néhány alapkérdése. 20-21.

http://gepeskonyv.btk.elte.hu/adatok/Pedagogia/84N\%E1dasi/Nyomtat\%E1sra/pdf/Csal\%E1d,\%20gyermek,\%20t\%E1rsadalom.pdf (Utolsó letöltés: 2020. 04. 17.) 


\section{TEMATIKUS TANULMÁNYOK - „Hetelők” Kelet-Magyarországon}

Magyar E. (2006): Szeretet? Az mi? In: Hegedűs J. (szerk.): A gyakorlati pedagógia néhány alapkérdése. 18-19.

http://gepeskonyv.btk.elte.hu/adatok/Pedagogia/84N\%E1 dasi/Nyomtat\%E1sra/pdf/Csal\%E1d,\%20gyermek,\%20t\%E1rsadalom.pdf (Utolsó letöltés: 2020. 04. 17.)

Murinkó L. (2013): Első elköltözés a szülői házból Magyarországon. A szülői ház elhagyásának időzítése, párkapcsolati környezete és családi háttér szerinti különbségei. KSH NKI Kutatási Jelentések 94. KSH Népességtudományi Kutatóintézet, Budapest

Murinkó L. (2014): Gyermekgondozási munkamegosztás és a nemi szerepek megítélése. In: Spéder Zs. (szerk.): A család vonzásában - tanulmányok Pongrácz Tiborné tiszteletére. KSH Népességtudományi Kutatóintézet. Budapest, 177-216. https://www.demografia.hu/kiadvanyokonline/index.php/demografuskonyvtar/article/view/2613 (Utolsó letöltés: 2020. 04. 20.)

Rane R. T. - McBride A. B. (2000): Identity Theory as a Guide to Understanding Fathers' Involvement With Their Children. Journal of Family Issues. Vol. 21. No. 3. 347-366.

Satir V. (1999): A család együttélésének művészete: új családműhely. Coincidencia Kft., Budapest

Schadt M. (szerk.) (2000): Családszociológia, szöveggyűjtemény. Pécs, Comenius

Sebők Cs. - Sik E. (2004): Az otthoni munka és a teljes élet. Statisztikai Szemle. 82. évf. 2. szám, 151-171.

http://www.ksh.hu/statszemle_archive/2004/2004_02/2004_02_151.pdf (Utolsó letöltés: 2020. 04. 20.)

Szczuka B. - Nagy B. - Tóbiás I. - Gulya F. (2018): A szülők munkavállalásának hatása gyermekeik jóllétére. Socio.hu Társadalomtudományi Szemle. 2018/4. 70-96. https://socio.hu/uploads/files/2018_4/30_szczuka.pdf (Utolsó letöltés: 2020. 04. 20.)

Thomsen, K. M. (2015): Parental time investments in children: Evidence from Denmark. Acta Sociologica. 58(3): 249-263.

Welch, G. (1987): An integrated approach to social work practice. McKendrick, B. W. (ed.): Introduction to social work in South Africa. Owen Burgess, Pinetown, 152-176.

Woods, R. (1994): A szociális munkások tevékenységeinek egy lehetséges rendszerezése. In: Hegyesi G. - Talyigás K. (szerk.): A szociális munka elmélete és gyakorlata 1. kötet. Nemzeti Család- és Szociálpolitikai Intézet, Budapest, 32-45. 